\title{
Stress Coping Strategies and Status of Job Burnout of Middle School Teachers in China
}

\author{
Huang Jiahui ${ }^{1 *}$ \\ ${ }^{1}$ Center for Teacher Education Research of Beijing Normal University, Beijing 100875, China \\ *Corresponding author. Email: jiahuibnu@163.com
}

\begin{abstract}
With the growing demand for the development of education, teachers are playing a more and more important role in education. Society, schools and parents also show higher and higher expectations for teachers, and the burden on teachers' shoulders is increasing gradually. Under the impact of various pressures, if teachers cannot adopt certain stress coping strategies, they are most likely to have the job burnout sense. This research investigates the stress coping strategies and status of job burnout of middle school teachers in China, analyzes and provides suggestions.
\end{abstract}

Keywords: Stress Coping Strategies, Job Burnout

\section{INSTRUCTION}

Nowadays, education has gradually become an important factor for the development of society and production. The Opinions on Deepening Educational Teaching Reform and Improving the Quality of Compulsory Education (2019) of the State Council of the CPC Central Committee also mentioned: "Reform and strengthen normal education, improve the quality of teacher training, and implement the cross training for all teachers". It can be seen that teachers are playing a more and more important role in education, and more and more attention has been paid to the cultivation and improvement of teachers' professional quality. Therefore, the society, schools and parents show high expectations for teachers, and the burden on teachers' shoulders is increasing gradually. In addition to daily teaching, teachers need to constantly improve their comprehensive quality and ability, update educational concepts and teaching methods to adapt to the new environment of course reform, and bear the pressure of social expectations, multiple roles, and job performance and so on. Under the impact of various pressures, if teachers cannot adopt certain stress coping strategies, they are most likely to have the job burnout sense.

At present, there are many researches on teachers' job burnout at home and abroad, but most of the existing researches are from a macro perspective, and the research on stress coping strategies as the entry point is even less. According to existing researches, it can be found that there are some differences in teachers' stress coping strategies and job burnout, as well as in demographic variables, and teachers' coping strategies will be different in teachers' educational degree, position and teaching age. Many researchers have found that there are differences in gender, teaching age and position ${ }^{[1][2][3]}$, Foreign scholar Antoniou (2013) found that there is a magical "curve" relationship between job burnout and teaching age. Teachers with 11-15 years of teaching experience are more likely to have emotional exhaustion due to working conditions than those with 1 10 years or more than 15 years of teaching experience. Teachers with more than 15 years of teaching experience have the lowest degree of emotional exhaustion, and teachers' teaching phases may also have a certain impact on their job burnout ${ }^{[4]}$.

This research starts from the stress coping strategies of teachers, and analyzes them from the theoretical perspective on the basis of understanding the status of teachers' job burnout; at the same time, this research provides suggestions for the choice of stress coping strategies of middle school teachers from the practical perspective, and alleviates the job burnout of contemporary middle school teachers from the perspective of stress coping strategies.

\section{RESEARCH METHOD}

\subsection{Research Object}

In this research, the stratified sampling method was adopted to investigate 3,601 middle school teachers from 50 middle schools in 20 provinces and cities across China, including 1,760 male teachers, accounting for 
$48.9 \%$, and 1,841 female teachers, accounting for $51.1 \%$. Among them, there are 748 teachers in urban areas, accounting for $20.8 \%$, and 2,853 teachers in rural areas, accounting for $79.2 \%$.

\subsection{Research Tool}

This research integrates the existing questionnaires, and compiles the Questionnaire on Stress Coping Strategies and Job Burnout of Middle School Teachers as the research tool, in addition to demographic data (including gender, educational background, teaching age, position, etc.), the questionnaire also includes the following two parts:

\subsubsection{Stress Coping Strategies of Teachers.}

This part of the scale is adapted from the COPE scale compiled by foreign scholar Carver (1989), with a total of 11 questions and 3 dimensions. The scale is scored by Likert 5 points. The higher the score, the more frequently the stress coping strategies of this dimension are adopted by middle school teachers. The $\alpha$ coefficient of the scale is 0.891 . The scale has good internal consistency.

\subsubsection{Job Burnout of Teachers.}

This part of the scale is adapted from Maslach's job burnout scale, with a total of 19 questions and 3 dimensions. The scale is scored by Likert 5 points. Except for the reduced personal accomplishment, the higher the score, the higher the level of teachers' job burnout. The $\alpha$ coefficient of the scale is 0.923 . The scale has good internal consistency.

\section{RESEARCH RESULT}

\subsection{The Status of Stress Coping Strategies of Middle School Teachers}

\subsubsection{Middle school teachers' stress coping shows a positive orientation.}

Table 1 shows the status of stress coping strategies of middle school teachers. Middle school teachers tend to adopt "positive and optimistic" stress coping strategies $(\mathrm{M}=3.73, \mathrm{SD}=0.54)$, while few middle school teachers adopt "negative and self-mocking" stress coping strategies ( $\mathrm{M}=2.78, \mathrm{SD}=0.88)$.

\subsubsection{To cope with the stress, male middle school teachers and urban teachers are more likely to be negative and self-mocking, while female middle school teachers tend to seek for support.}

Independent sample $\mathrm{t}$ was used to test the stress coping strategies of middle school teachers of different genders and urban-rural areas, and the differences were analyzed. the results are shown in Table 1. To cope with the stress, male teachers are more likely to be "negative and self-mocking" $(\mathrm{t}=4.12 * *$, Cohens' $\mathrm{d}=0.17)$, female teachers are more likely to "seek for support" ( $\mathrm{t}=-$ $7.46^{* *}$, Cohens' $\mathrm{d}=0.25$ ), while urban teachers are more likely to use "negative and self-mocking" stress coping strategies $\left(\mathrm{t}=7.30^{* *}\right.$, Cohens' $\left.\mathrm{d}=0.30\right)$.

Table 1 The Status of Stress Coping Method of Middle School Teachers and the Gender Difference, Urban and Rural Areas $(n=3601)$

\begin{tabular}{|c|c|c|c|c|c|c|c|c|c|}
\hline & \multirow[b]{2}{*}{$\begin{array}{c}M \\
(\mathrm{SD})\end{array}$} & \multicolumn{4}{|c|}{ Gender Difference } & \multicolumn{4}{|c|}{ Urban and Rural Difference } \\
\hline & & $\begin{array}{c}\text { Male } \\
\text { M } \\
(S D)\end{array}$ & $\begin{array}{c}\text { Female } \\
\text { M } \\
(\mathrm{SD})\end{array}$ & $\mathrm{t}$ & Cohens'd & $\begin{array}{c}\text { Urban } \\
\text { M } \\
(\mathrm{SD})\end{array}$ & $\begin{array}{c}\text { Rural } \\
\text { M } \\
(S D)\end{array}$ & $\mathrm{t}$ & Cohens'd \\
\hline $\begin{array}{l}\text { Positive and } \\
\text { Optimistic }\end{array}$ & $\begin{array}{c}3.73 \\
(0.54)\end{array}$ & $\begin{array}{c}3.72 \\
(0.55)\end{array}$ & $\begin{array}{c}3.74 \\
(0.53)\end{array}$ & -1.03 & 0.04 & $\begin{array}{c}3.72 \\
(0.52)\end{array}$ & $\begin{array}{l}3.74 \\
(0.54)\end{array}$ & -0.77 & 0.04 \\
\hline $\begin{array}{l}\text { Seek for } \\
\text { Support }\end{array}$ & $\begin{array}{c}3.50 \\
(0.61)\end{array}$ & $\begin{array}{c}3.42 \\
(0.61)\end{array}$ & $\begin{array}{c}3.57 \\
(0.61)\end{array}$ & $\overline{-}^{-}$ & 0.25 & $\begin{array}{c}3.53 \\
(0.62)\end{array}$ & $\begin{array}{c}3.49 \\
(0.61)\end{array}$ & 1.91 & 0.07 \\
\hline $\begin{array}{l}\text { Negative } \\
\text { and Self- } \\
\text { mocking }\end{array}$ & $\begin{array}{c}2.78 \\
(0.88)\end{array}$ & $\begin{array}{c}2.84 \\
(0.88)\end{array}$ & $\begin{array}{c}2.72 \\
(0.88)\end{array}$ & $4.12^{\star \star}$ & 0.17 & $\begin{array}{c}2.98 \\
(0.85)\end{array}$ & $\begin{array}{c}2.72 \\
(0.88)\end{array}$ & $7.30^{\star *}$ & 0.30 \\
\hline
\end{tabular}

Note: Cohens'd is 0.2, 0.5 and 0.8 , representing small, medium and large effects, respectively. $* \mathrm{p}<0.01, * * \mathrm{p}<0.001$ 
3.1.3. To cope with the stress, teachers with lower teaching age are more likely to seek for support and be negative and self-mocking, senior teachers are more likely to seek for support and be negative and self-mocking than teachers with other professional titles.

One-way ANOVA was used to analyze the differences of stress coping strategies of middle school teachers with different teaching ages and professional titles. The results are shown in Table 2 and Table 3. There are significant differences among teachers with different teaching ages in "seeking for support"
$\left(\mathrm{F}(3601)=15.11^{* *}, \eta 2=0.010\right)$ and "negative and selfmocking" stress coping strategies $\left(\mathrm{F}(3601)=15.11^{* *}\right.$, $\eta 2=0.010$ ). Among them, middle school teachers with more than 20 years of teaching age are less likely to "seek for support", while middle school teachers with less than 5 years of teaching age are more likely to be "negative and self-mocking". There are significant differences among middle school teachers with different professional titles in "seeking for support" $(\mathrm{F}(3601)=8.94 * *, \eta 2=0.017)$ and "negative and selfmocking" stress coping strategies $(\mathrm{F}(3601)=8.79 * *$, $\eta 2=0.029$ ). Middle school teachers with senior professional titles are more likely to "seek for support" and be "negative and self-mocking".

Table 2 The Status of Stress Coping Method of Middle School Teachers and the Difference of Teaching Age $(\mathrm{n}=3601)$

\begin{tabular}{|c|c|c|c|c|c|c|c|c|}
\hline & \multirow[b]{2}{*}{$\begin{array}{c}M \\
(S D)\end{array}$} & \multicolumn{7}{|c|}{ Difference of Professional Title } \\
\hline & & $\begin{array}{c}\text { Senior } \\
\text { Teacher } \\
\text { M } \\
\text { (SD) }\end{array}$ & $\begin{array}{c}\text { Senior } \\
\text { Teacher } \\
\text { M } \\
\text { (SD) }\end{array}$ & $\begin{array}{c}\text { First- } \\
\text { grade } \\
\text { Teacher } \\
\text { M } \\
\text { (SD) }\end{array}$ & $\begin{array}{l}\text { Second- } \\
\text { grade } \\
\text { Teacher } \\
\text { M } \\
\text { (SD) }\end{array}$ & $\begin{array}{c}\text { Third- } \\
\text { grade } \\
\text { Teacher } \\
\text { M } \\
\text { (SD) }\end{array}$ & $\mathrm{F}$ & $\eta^{2}$ \\
\hline $\begin{array}{l}\text { Positive } \\
\text { and } \\
\text { Optimistic }\end{array}$ & $\begin{array}{c}3.73 \\
(0.54)\end{array}$ & $\begin{array}{c}3.74 \\
(0.47)\end{array}$ & $\begin{array}{c}3.68 \\
(0.57)\end{array}$ & $\begin{array}{c}3.76 \\
(0.55)\end{array}$ & $\begin{array}{c}3.72 \\
(0.53)\end{array}$ & $\begin{array}{c}3.73 \\
(0.56)\end{array}$ & 1.02 & 0.001 \\
\hline $\begin{array}{l}\text { Seek for } \\
\text { Support }\end{array}$ & $\begin{array}{l}3.50 \\
(0.61)\end{array}$ & $\begin{array}{c}3.56 \\
(0.50)\end{array}$ & $\begin{array}{c}3.73 \\
(0.60)\end{array}$ & $\begin{array}{c}3.59 \\
(0.62)\end{array}$ & $\begin{array}{c}3.46 \\
(0.61)\end{array}$ & $\begin{array}{c}3.45 \\
(0.64)\end{array}$ & $8.94^{\star *}$ & 0.017 \\
\hline $\begin{array}{l}\text { Negative } \\
\text { and Self- } \\
\text { mocking }\end{array}$ & $\begin{array}{c}2.78 \\
(0.88)\end{array}$ & $\begin{array}{c}2.90 \\
(0.89)\end{array}$ & $\begin{array}{c}2.98 \\
(0.94)\end{array}$ & $\begin{array}{c}2.91 \\
(0.89)\end{array}$ & $\begin{array}{c}2.71 \\
(0.88)\end{array}$ & $\begin{array}{c}2.82 \\
(0.87)\end{array}$ & $8.79^{* *}$ & 0.029 \\
\hline
\end{tabular}

Note: Cohens'd is $0.2,0.5$ and 0.8 , representing small, medium and large effects, respectively. ${ }^{*} \mathrm{p}<0.01,{ }^{* *} \mathrm{p}<0.001$

Table 3 The Status of Stress Coping Method of Middle School Teachers and the Difference of Professional Title $(\mathrm{n}=3601)$

\begin{tabular}{|c|c|c|c|c|c|c|c|c|}
\hline & \multirow[b]{2}{*}{$\begin{array}{c}M \\
(\mathrm{SD})\end{array}$} & \multicolumn{7}{|c|}{ Difference of Teaching Age } \\
\hline & & $\begin{array}{c}0-5 \\
\text { Years } \\
M \\
(\mathrm{SD})\end{array}$ & $\begin{array}{c}5-10 \\
\text { Years } \\
M \\
(S D)\end{array}$ & $\begin{array}{c}10-15 \\
\text { Years } \\
M \\
(\mathrm{SD})\end{array}$ & $\begin{array}{c}15-20 \\
\text { Years } \\
M \\
(S D)\end{array}$ & $\begin{array}{c}\text { More } \\
\text { Than } 20 \\
\text { Years } \\
\text { M } \\
\text { (SD) }\end{array}$ & $\mathrm{F}$ & $\eta^{2}$ \\
\hline $\begin{array}{l}\text { Positive } \\
\text { and } \\
\text { Optimistic }\end{array}$ & $\begin{array}{c}3.73 \\
(0.54)\end{array}$ & $\begin{array}{c}3.73 \\
(0.53)\end{array}$ & $\begin{array}{c}3.74 \\
(0.52)\end{array}$ & $\begin{array}{c}3.71 \\
(0.54)\end{array}$ & $\begin{array}{c}3.72 \\
(0.55)\end{array}$ & $\begin{array}{c}3.75 \\
(0.54)\end{array}$ & 0.72 & 0.001 \\
\hline $\begin{array}{l}\text { Seek for } \\
\text { Support }\end{array}$ & $\begin{array}{c}3.50 \\
(0.61)\end{array}$ & $\begin{array}{c}3.69 \\
(0.61)\end{array}$ & $\begin{array}{c}3.59 \\
(0.61)\end{array}$ & $\begin{array}{c}3.50 \\
(0.54)\end{array}$ & $\begin{array}{c}3.51 \\
(0.54)\end{array}$ & $\begin{array}{c}3.42 \\
(0.62)\end{array}$ & $15.11^{* *}$ & 0.010 \\
\hline $\begin{array}{l}\text { Negative } \\
\text { and Self- } \\
\text { mocking }\end{array}$ & $\begin{array}{c}2.78 \\
(0.88)\end{array}$ & $\begin{array}{c}3.19 \\
(0.88)\end{array}$ & $\begin{array}{c}2.92 \\
(0.88)\end{array}$ & $\begin{array}{c}2.79 \\
(0.54)\end{array}$ & $\begin{array}{c}2.82 \\
(0.54)\end{array}$ & $\begin{array}{c}2.63 \\
(0.85)\end{array}$ & $27.17^{\star *}$ & 0.010 \\
\hline
\end{tabular}

Note: Cohens'd is 0.2, 0.5 and 0.8 , representing small, medium and large effects, respectively. ${ }^{*} \mathrm{p}<0.01,{ }^{*} \mathrm{p}<0.001$ 


\subsection{The Status of Job Burnout of Middle School Teachers}

\subsubsection{The level of job burnout of middle school teachers is not high, but the emotional exhaustion is more serious.}

Table 4 shows the status of job burnout of middle school teachers, it can be seen that the job burnout of middle school teachers is in the middle level $(\mathrm{M}=2.34$, $\mathrm{SD}=0.60$ ), but the emotional exhaustion is the most serious $(\mathrm{M}=2.51, \mathrm{SD}=0.78)$.

Table 4 The Status of Job Burnout of Middle School Teachers and the Gender Difference, Urban and Rural Areas $(n=3601)$

\begin{tabular}{|c|c|c|c|c|c|c|c|c|c|}
\hline & \multirow[b]{2}{*}{$\begin{array}{c}M \\
(\mathrm{SD})\end{array}$} & \multicolumn{4}{|c|}{ Gender Difference } & \multicolumn{4}{|c|}{ Urban and Rural Difference } \\
\hline & & $\begin{array}{c}\text { Male } \\
\text { M } \\
(\mathrm{SD})\end{array}$ & $\begin{array}{c}\text { Female } \\
M \\
(\mathrm{SD})\end{array}$ & $\mathrm{t}$ & $\begin{array}{c}\text { Cohens } \\
\text { 'd }\end{array}$ & $\begin{array}{c}\text { Urban } \\
\text { M } \\
\text { (SD) }\end{array}$ & $\begin{array}{c}\text { Rural } \\
M \\
(S D)\end{array}$ & $\mathrm{t}$ & $\begin{array}{c}\text { Cohens } \\
\text { 'd }\end{array}$ \\
\hline $\begin{array}{l}\text { Emotional } \\
\text { Exhaustion }\end{array}$ & $\begin{array}{c}2.51 \\
(0.78)\end{array}$ & $\begin{array}{c}2.53 \\
(0.80)\end{array}$ & $\begin{array}{c}2.50 \\
(0.76)\end{array}$ & 1.23 & 0.04 & $\begin{array}{c}2.59 \\
(0.77)\end{array}$ & $\begin{array}{c}2.49 \\
(0.78)\end{array}$ & $3.18^{*}$ & 0.13 \\
\hline $\begin{array}{l}\text { Deindividu } \\
\text { ation } \\
\text { Reduced }\end{array}$ & $\begin{array}{c}2.17 \\
(0.72)\end{array}$ & $\begin{array}{c}2.20 \\
(0.76)\end{array}$ & $\begin{array}{l}2.14 \\
(0.67)\end{array}$ & $2.85^{\star}$ & 0.08 & $\begin{array}{c}2.28 \\
(0.72)\end{array}$ & $\begin{array}{l}2.14 \\
(0.71)\end{array}$ & $4.58^{* *}$ & 0.20 \\
\hline $\begin{array}{c}\text { Personal } \\
\text { Accomplis } \\
\text { hment }\end{array}$ & $\begin{array}{c}2.26 \\
(0.57)\end{array}$ & $\begin{array}{c}2.23 \\
(0.59)\end{array}$ & $\begin{array}{l}2.29 \\
(0.55)\end{array}$ & $-3.51^{* *}$ & 0.11 & $\begin{array}{c}2.25 \\
(0.53)\end{array}$ & $\begin{array}{c}2.26 \\
(0.58)\end{array}$ & -0.74 & 0.02 \\
\hline $\begin{array}{c}\text { Job } \\
\text { Burnout }\end{array}$ & $\begin{array}{c}2.34 \\
(0.60)\end{array}$ & $\begin{array}{c}2.35 \\
(0.62)\end{array}$ & $\begin{array}{c}2.34 \\
(0.58)\end{array}$ & 0.52 & 0.02 & $\begin{array}{c}2.40 \\
(0.58)\end{array}$ & $\begin{array}{c}2.33 \\
(0.60)\end{array}$ & $2.97^{\star}$ & 0.12 \\
\hline
\end{tabular}

\subsubsection{The deindividuation of male middle school} teachers is more serious, but the sense of achievement is higher, and the job burnout of urban middle school teachers is more serious.

Independent sample $t$ was used to test the level of job burnout of middle school teachers of different genders and urban-rural areas, and the differences were analyzed. The results are shown in Table 4. The deindividuation of male teachers is more serious $\left(\mathrm{t}=2.85^{*}, \quad\right.$ Cohens' $\left.\mathrm{d}=0.08\right)$, the reduced personal accomplishment of female teachers is more serious $(\mathrm{t}=-$ $3.51^{* *}$, Cohens' $\mathrm{d}=0.11$ ), and the emotional exhaustion $\left(\mathrm{t}=3.18^{*}\right.$, Cohens' $\left.\mathrm{d}=0.13\right)$, deindividuation $(\mathrm{t}=4.58 * *$, Cohens'd $=0.20)$ and job burnout $\left(\mathrm{t}=2.97^{*}\right.$, Cohens' $d=0.12$ ) of urban teachers are more serious.

\subsubsection{The job burnout of novice middle school} teachers is serious, and the higher the professional title and teaching age of middle school teachers are, the lower the sense of achievement is. Emotional exhaustion, deindividuation and job burnout show two turning points.

One-way ANOVA was used to analyze the differences of the level of job burnout of middle school teachers with different teaching ages and professional titles. The results are shown in Table 5 and Table 6. There are significant differences among teachers with different teaching ages in "seeking for support" $\left(F(3601)=15.11^{* *}, \eta 2=0.010\right)$ and "negative and selfmocking" stress coping strategies $\left(\mathrm{F}(3601)=15.11^{* *}\right.$, $\eta 2=0.010$ ). The level of job burnout of middle school teachers with different teaching ages and professional titles was analyzed by single factor analysis of variance (One-way ANOVA). The results are shown in tables 5 and 6. There are significant differences among teachers of different teaching ages in emotional exhaustion $\left(\mathrm{F}(3601)=2.47^{*}, \quad \eta 2=0.003\right), \quad$ deindividuation $(\mathrm{F}(3601)=17.74 * *, \quad \eta 2=0.019), \quad$ reduced personal accomplishment $\left(\mathrm{F}(3601)=13.90^{* *}, \eta 2=0.015\right)$ and job burnout $\left(\mathrm{F}(3601)=9.80^{*}, \eta 2=0.003\right)$. Among them, deindividuation of middle school teachers with less than 5 years of teaching age is more serious. In general, the job burnout of middle school teachers with more than 20 years of teaching age is more minor. There are significant differences among middle school teachers with different professional titles in deindividuation $\left(\mathrm{F}(3601)==2.91^{*}, \eta 2=0.003\right)$ and reduced personal accomplishment $\quad\left(\mathrm{F}(3601)=6.15^{* *}, \quad \eta 2=0.007\right) . \quad$ The deindividuation of middle school teachers with firstgrade professional titles is more serious, and the reduced personal accomplishment of middle school teachers with senior professional titles is more serious. 
Table 5 The Status of Job Burnout of Middle School Teachers and the Difference of Teaching Age (n=3601)

\begin{tabular}{|c|c|c|c|c|c|c|c|c|}
\hline & \multirow[b]{2}{*}{$\begin{array}{c}\mathrm{M} \\
(\mathrm{SD})\end{array}$} & \multicolumn{7}{|c|}{ Difference of Teaching Age } \\
\hline & & $\begin{array}{c}0-5 \\
\text { Years } \\
M \\
(S D)\end{array}$ & $\begin{array}{l}5-10 \\
\text { Years } \\
M \\
(S D)\end{array}$ & $\begin{array}{c}10-15 \\
\text { Years } \\
M \\
(S D)\end{array}$ & $\begin{array}{c}15-20 \\
\text { Years } \\
M \\
(S D)\end{array}$ & $\begin{array}{c}\text { More } \\
\text { Than } 20 \\
\text { Years } \\
\text { M } \\
\text { (SD) }\end{array}$ & $\mathrm{F}$ & $\eta^{2}$ \\
\hline $\begin{array}{l}\text { Emotional } \\
\text { Exhaustion }\end{array}$ & $\begin{array}{c}2.51 \\
(0.78)\end{array}$ & $\begin{array}{c}2.58 \\
(0.80)\end{array}$ & $\begin{array}{c}2.49 \\
(0.74)\end{array}$ & $\begin{array}{c}2.57 \\
(0.76)\end{array}$ & $\begin{array}{c}2.53 \\
(0.83)\end{array}$ & $\begin{array}{l}2.47 \\
(0.79)\end{array}$ & $2.47^{*}$ & 0.003 \\
\hline $\begin{array}{l}\text { Deindividu } \\
\text { ation }\end{array}$ & $\begin{array}{c}2.17 \\
(0.72)\end{array}$ & $\begin{array}{c}2.37 \\
(0.72)\end{array}$ & $\begin{array}{c}2.24 \\
(0.68)\end{array}$ & $\begin{array}{c}2.24 \\
(0.71)\end{array}$ & $\begin{array}{c}2.22 \\
(0.74)\end{array}$ & $\begin{array}{c}2.05 \\
(0.71)\end{array}$ & $17.74^{\star *}$ & 0.019 \\
\hline $\begin{array}{c}\text { Reduced } \\
\text { Personal } \\
\text { Accomplish } \\
\text { ment }\end{array}$ & $\begin{array}{c}2.26 \\
(0.57)\end{array}$ & $\begin{array}{c}2.41 \\
(0.68)\end{array}$ & $\begin{array}{c}2.33 \\
(0.57)\end{array}$ & $\begin{array}{c}2.30 \\
(0.57)\end{array}$ & $\begin{array}{c}2.25 \\
(0.56)\end{array}$ & $\begin{array}{l}2.19 \\
(0.57)\end{array}$ & $13.90^{* *}$ & 0.015 \\
\hline $\begin{array}{c}\text { Job } \\
\text { Burnout }\end{array}$ & $\begin{array}{c}2.34 \\
(0.60)\end{array}$ & $\begin{array}{c}2.47 \\
(0.61)\end{array}$ & $\begin{array}{c}2.38 \\
(0.57)\end{array}$ & $\begin{array}{c}2.40 \\
(0.59)\end{array}$ & $\begin{array}{c}2.36 \\
(0.62)\end{array}$ & $\begin{array}{l}2.27 \\
(0.60)\end{array}$ & $9.80^{* *}$ & 0.003 \\
\hline
\end{tabular}

Note: Cohens'd is 0.2, 0.5 and 0.8, representing small, medium and large effects, respectively. ${ }^{*} \mathrm{p}<0.01, * * \mathrm{p}<0.001$

Table 6 The Status of Job Burnout of Middle School Teachers and the Difference of Professional Title (n=3601)

\begin{tabular}{|c|c|c|c|c|c|c|c|c|}
\hline & \multirow[b]{2}{*}{$\begin{array}{c}M \\
(\mathrm{SD})\end{array}$} & \multicolumn{7}{|c|}{ Difference of Professional Title } \\
\hline & & $\begin{array}{c}\text { Senior } \\
\text { Teacher } \\
\text { M } \\
\text { (SD) }\end{array}$ & $\begin{array}{c}\text { Senior } \\
\text { Teacher } \\
\text { M } \\
\text { (SD) }\end{array}$ & $\begin{array}{c}\text { First- } \\
\text { grade } \\
\text { Teacher } \\
\text { M } \\
\text { (SD) }\end{array}$ & $\begin{array}{l}\text { Second- } \\
\text { grade } \\
\text { Teacher } \\
\text { M } \\
(\mathrm{SD})\end{array}$ & $\begin{array}{c}\text { Third- } \\
\text { grade } \\
\text { Teacher } \\
\text { M } \\
(\mathrm{SD})\end{array}$ & $\mathrm{F}$ & $\eta^{2}$ \\
\hline $\begin{array}{l}\text { Emotional } \\
\text { Exhaustion }\end{array}$ & $\begin{array}{c}2.51 \\
(0.78)\end{array}$ & $\begin{array}{c}2.49 \\
(0.84)\end{array}$ & $\begin{array}{l}2.36 \\
(0.67)\end{array}$ & $\begin{array}{c}2.52 \\
(0.78)\end{array}$ & $\begin{array}{c}2.51 \\
(0.78)\end{array}$ & $\begin{array}{c}2.49 \\
(0.77)\end{array}$ & 0.27 & 0.000 \\
\hline $\begin{array}{l}\text { Deindividu } \\
\text { ation }\end{array}$ & $\begin{array}{c}2.17 \\
(0.72)\end{array}$ & $\begin{array}{c}2.19 \\
(0.73)\end{array}$ & $\begin{array}{l}2.09 \\
(0.65)\end{array}$ & $\begin{array}{l}2.24 \\
(0.72)\end{array}$ & $\begin{array}{l}2.15 \\
(0.72)\end{array}$ & $\begin{array}{l}2.11 \\
(0.70)\end{array}$ & $2.91^{*}$ & 0.003 \\
\hline $\begin{array}{c}\text { Reduced } \\
\text { Personal } \\
\text { Accomplis } \\
\text { hment }\end{array}$ & $\begin{array}{c}2.26 \\
(0.57)\end{array}$ & $\begin{array}{c}2.43 \\
(0.51)\end{array}$ & $\begin{array}{c}2.35 \\
(0.49)\end{array}$ & $\begin{array}{c}2.30 \\
(0.57)\end{array}$ & $\begin{array}{c}2.25 \\
(0.57)\end{array}$ & $\begin{array}{c}2.14 \\
(0.58)\end{array}$ & $6.15^{\star \star}$ & 0.007 \\
\hline $\begin{array}{c}\text { Job } \\
\text { Burnout }\end{array}$ & $\begin{array}{c}2.34 \\
(0.60)\end{array}$ & $\begin{array}{c}2.39 \\
(0.62)\end{array}$ & $\begin{array}{c}2.28 \\
(0.56)\end{array}$ & $\begin{array}{l}2.38 \\
(0.60)\end{array}$ & $\begin{array}{c}2.34 \\
(0.60)\end{array}$ & $\begin{array}{l}2.28 \\
(0.60)\end{array}$ & 1.81 & 0.002 \\
\hline
\end{tabular}

\section{CONCLUSION AND DISCUSSION}

\subsection{Pay attention to the teachers who are "negative and self-mocking" under the press.}

"Positive and optimism" and "seeking for support" are positive stress coping strategies, which can be seen that positive coping strategies are more easily adopted by middle school teachers in the face of stress, which is also consistent with the conclusions reached by previous scholars ${ }^{[3][4][9]}$, In the face of stress, middle school teachers can maintain a positive orientation in both attitude and behavior. However, through the analysis of the differences of demographic variables, this research found that male teachers, urban teachers, teachers with lower teaching age and senior teachers tend to adopt "negative and self-mocking" coping strategies in the face of stress.

The score of negative coping of male teachers is higher than that of female teachers. In the face of stress, men tend to solve problems alone in order to maintain their own image and self-esteem, but lack of communication and external help ${ }^{[2]}$. Vincent N.Parrillo said, "All societies regulate the behavior and patterns of social interaction. Among these cultural regulations and role expectations, there are also institutionalized standards for gender differences" ${ }^{[10]}$. In fact, the behavior of men and women is determined by the cultural norms of gender roles to a certain extent. This research found that middle school teachers in urban areas tend to adopt "negative and self-mocking" coping 
strategies in the face of stress. Some studies indicate that the stress of rural teachers is significantly less than that of urban teachers ${ }^{[11]}$, the high pressure exerted by urban education on teachers and the weakening network connection of human-to-human are all possible reasons for this result.

Teachers with lower teaching age tend to be "negative and self-mocking", which is due to the fact that novice teachers are new to the position and have less experience ${ }^{[1]}$. Emotional intelligence is the ability of individuals to monitor their own and other people's emotions, and to distinguish, identify and use these information to guide their own thoughts and behaviors ${ }^{[12]}$, which is a series of skills and traits that help people adapt to the social and emotional needs of life ${ }^{[13]}$. If novice teachers can perceive and express their emotions more reasonably and accurately, regulate their negative emotions, release and transfer their negative emotions through reasonable methods, it will have great significance for them to cope with stress. With the rise of the grade evaluation of professional titles, the evaluation standards and conditions are relatively stricter, and teachers need to have more experience, honorary titles, teaching characteristics and educational achievements. Through the results of this research, it can be found that when teachers come to the stage of professional titles of senior teachers, there are two completely different stress coping strategies. They not only need external support, but also need channels to regulate and release stress and negative emotions, which is often ignored by school leaders, education departments and society because of the stereotype of senior teachers.

\subsection{Master the law of teachers' job burnout and take preventive measures.}

This research found that the current job burnout of middle school teachers is in the middle level, in which the emotional exhaustion perceived by teachers is the most serious. The deindividuation of male teachers is more serious than that of female teachers, which is consistent with the results of previous researches. Men are more persistent and ruthless, and male teachers are more likely to have a cold and alienated attitude in the face of stress ${ }^{[1]}$, professional roles are gender-typed, and female teachers account for the majority of teachers in the education industry. Male teachers often get a strange eyes when they enter the feminine field, so they are sensitive, self-abased and alienated ${ }^{[14]}$. On the other hand, men are often influenced by the social values of "work achievement and income" are standards of success and value. The low income of middle school teachers is also likely to lead to low enthusiasm, indifference and alienation from their work. The reduced personal achievement of female teachers is more serious than that of male teachers. Meade believes that "culture always takes great pains and seeks by all means to make the next newborn grow up according to the established cultural image under complex conditions." ${ }^{[15]}$. It is precisely because the gender division of labor in modern society continues the traditional thoughts that men "go out" and women "stay home", "a woman without talent is virtuous" has become the invisible rule to force women. As Ferrudo believes, society does not emphasize women's high desire for achievement in intelligence and leadership, but encourages them to achieve achievement in social skills ${ }^{[16]}$. Compared with rural teachers, urban teachers face a more serious problem of job burnout, and their emotional exhaustion and deindividuation level is also higher than that of rural teachers, which is consistent with the existing research results ${ }^{[1]}$. Under the high pressure of life in rural areas, teachers' meaningless and repetitive work aggravates teachers' burden, and gradually loses their passion and enthusiasm for the education, which should be paid attention to by the relevant departments; in the face of the indifference and alienation of the education, the organizational support and cultural atmosphere of the school should play a cohesive role in the teacher team.

Foreign scholar Antoniou found that there is a magical "curve" relationship between job burnout and teaching age. Teachers with 11-15 years of teaching experience are more likely to have emotional exhaustion than those with 1-10 years or more than 15 years of teaching experience, and teachers with more than 15 years of teaching experience have the lowest degree of emotional exhaustion ${ }^{[4]}$. Likewise, this research found that there are two "turning points" between job burnout and teaching age, as well as between job burnout and professional title. In conclusion, teachers' job burnout may show a higher level in the middle of their career, and then it may be alleviated in a short period, but it may be intensified in the later period the career. In the process of teachers' development, we should not only pay attention to the inadaptability of novice teachers entering the field of education, but also pay attention to the burnout of middle-aged teachers in the middle of their careers, so as to help them get through the bottleneck period, at the same time, through the "nentoring" of expert teachers with more experience and more qualifications, we can promote the development of novice teachers and enhance the sense of achievement and fulfillment of expert teachers.

\section{REFERENCES}

[1] Tong Cong, Research on the Relationship between Stress Coping and Job Burnout of Primary School Teachers in Xi'an [D]. Shaanxi: Northwest University, 2010.

[2] Hua Weiyan. Research on the Relationship between Occupational Stress, Coping Method, Job Burnout 
and Psychological Capital of Primary and Middle School Teachers [D]. Liaoning: Shenyang Normal University, 2018.

[3] Zhang Lu. Research on the Relationship between Occupational Stress, Coping Method and Job Burnout of Middle School Teachers [D]. Guangxi: Guangxi Normal University, 2014.

[4] Antoniou A S, Ploumpi A, Ntalla M. Occupational Stress and Professional Burnout in Teachers of Primary and Secondary Education: The Role of Coping Strategies [J]. Psychology, 2013, 4(3A): 349-355.

[5] Xu Fuming, An Lianyi, Niu Fang. Research on the Coping Strategies of Job Burnout and Occupational Stress of Primary and Middle School Teachers [J]. Chinese Journal of School Health, 2004(05): 569570.

[6] Shin H., Park Y. M., Ying J. Y., et al. Relationships between coping strategies and burnout symptoms: A meta-analytic approach [J]. Professional Psychology: Research and Practice, 2014, 45(1): 44-56.

[7] Halbesleben, Jonathon R. B. Sources of Social Support and Burnout: A Meta-Analytic Test of the Conservation of Resources Model [J]. Journal of Applied Psychology, 2006, 91(5): 1134.

[8] Seidman, Steven A, Zager, Joanne. A study of coping behaviors and teacher burnout [J]. Work \& Stress, 1991, 5(3): 205-216.

[9] Zhao Haiyun. Research on the Relationship between Occupational Stress, Coping Strategies and Job Burnout of Preschool Teachers [D]. Heilongjiang: Harbin Engineering University, 2013.

[10] (America) Vincent N.Parrillo, etc. Contemporary Social Problems [M]. Translated by Zhou Bing, etc. Beijing: Huaxia Publishing House, 2002: 244.

[11] Yan Fangfang. Research on the Difference of Occupational Stress of Rural Primary School Teachers in Urban and Rural Fringe Areas [J]. Journal of Yan'an Vocational \& Technical College, 2014, 28(03): 68-69.

[12] Salovey, P. \& Mayer, J. D. Emotional intelligence [J]. Imagination, Cognition and Personality, 1990, 9(6): 185-211.

[13] Bar-On, R. The Bar-On model of emotional-social intelligence (ESI) [J]. Psicothema, 2006(18): 1325.

[14] (America) S. E. Taylor, L. A. Peplau, D. O. Sears. Social Psychology. Translated by Xie Xiaofei. Beijing: Peking University Press, 2004: 363-364.
[15] Margaret Mead. Gender and Temperament of the Three Primitive Tribes [M]. Hang Zhou: Zhejiang People's Publishing House, 1988.

[16] Yuan Zhenguo, Zhu Yongxin, Xue Lequn, Xu Weimin. Psychology of Differences between Men and Women $[\mathrm{M}]$. Tianjin: Tianjin People's Publishing House, 1989. 